\title{
ELASTOMER TESTING: THE RISK OF USING ONLY UNIAXIAL DATA FOR FITTING THE MOONEY-RIVLIN HYPERELASTIC-MATERIAL MODEL
}

\author{
TESTIRANJE ELASTOMEROV: RIZIKO UPORABE REZULTATOV \\ ENOOSNIH PREIZKUSOV ZA PRILAGAJANJE \\ MOONEY-RIVLINOVEMU MODELU ZA HIPERELASTIČNI \\ MATERIAL
}

\author{
Rohitha Keerthiwansa, Jakub Javorik, Jan Kledrowetz, Pavel Nekoksa \\ Tomas Bata University in Zlín, Faculty of Technology, Vavreckova 275, 76001 Zlín, Czech Republic \\ keerthiwansa@utb.cz \\ Prejem rokopisa - received: 2017-06-27; sprejem za objavo - accepted for publication: 2017-10-20
}

doi: $10.17222 /$ mit.2017.085

\begin{abstract}
The Mooney-Rivlin constitutive model is often used for the characterization of hyperelastic rubber-like materials. To obtain the material constants for a model, only a uniaxial-tension-data set is usually used. Though it is regularly used for its easiness of processing data in a simple and practical way, the method is considered to be insufficiently accurate. To analyse the shortcoming of the method, a detailed examination was done with the Mooney-Rivlin two-parameter model. This paper discusses the variations related to three basic load curves, i.e., uniaxial, equibiaxial and pure-shear curves. For a visual observation of the fitted-data dispersion, two data-fitting cases were considered. The first one was the data fitting only through uniaxial data while the second one was a combination of uniaxial and pure-shear experimental-data curve fitting. A detailed one-to-one comparison of the curves was done to achieve an accurate estimation of the variations.

Keywords: uniaxial tension, equibiaxial loading, pure shear/planar shear loading, curve fitting, Mooney-Rivlin constitutive model

Mooney-Rivlinov temeljni model se pogosto uporablja za karakterizacijo gumi podobnih hiperelastičnih materialov. Za materialne konstante se običajno uporablja set podatkov, dobljenih z enoosnim nateznim preizkusom. Čeprav se ta način uporablja zaradi enostavnosti in praktičnosti metode pa ga lahko smatramo kot manj natančnega. Zato, da bi avtorji tega prispevka ugotovili neskladje, so izvedli natančno analizo z Mooney-Rivlinovim dvoparametričnim modelom. V članku avtorji obravnavajo variacije, ki se nanašajo na tri osnovne krivulje obremenjevanja: enoosno, ekvivalentno dvoosno in čisti strig. Vizualno opazovanje raztrosa prilagojenih podatkov so izvedli na osnovi dveh načinov prilagajanja podatkov. Prvo prilagajanje podatkov so izvedli na osnovi rezultatov enoosnega nateznega preizkusa. V drugem primeru so uporabili kombinacijo obeh: eksperimentalne rezultate enoosnega nateznega preizkusa in čistega striga. Izvedli so natančno primerjavo krivulj in ocenili odstopanja.

Ključne besede: enoosni nateg, ekvivalentna biaksialna obremenitev, čisti strig, ravninska strižna obremenitev, prilagajanje krivulje, Mooney-Rivlinov konstitutivni (temeljni) model
\end{abstract}

\section{INTRODUCTION}

Hyperelastic rubber-like materials are often used in the industry for the construction of various machine components due to their specific material properties. During the design stage of these parts, in order to compensate for the behaviour under real-time load conditions, it is important to know the exact mechanical characteristics of these materials. As they behave nonlinearly during large deformations, stress-strain curves deviate from the typical pattern, therefore being difficult to estimate. The most common method of finding these characteristics at present is through several constitutive models introduced by various scientists. ${ }^{1-4}$

Once an appropriate model is selected, it needs material constants attached to it to complete the task of material characterization. The method used to obtain these material constants for a specific model is the fitting of the data collected from stress-strain experiments. The least squares approach of the numerical analysis is used to mathematically solve this problem. ${ }^{5,6}$

\subsection{Data fitting}

Data fitting is an important element in the process. Therefore, it is essential to pay attention to the procedure to do it in a proper manner. Because of the simplicity of the method of data acquisition, quite often the data collected through a uniaxial-tension test is used. According to M. Sasso et al. ${ }^{7}$ and others, the use of a single data set related to one particular mode of load is insufficient to obtained accurate results. The failure of the material characterization occurring due to this inadequacy of the data set during the data-fitting stage so far has not been properly estimated. The objective of this paper is to highlight the error imposed on the material characterization when using only uniaxial data for the data-fitting 
task compared to the combined, uniaxial and planarshear data fitting. Initially, in our effort, the MooneyRivlin two-parameter model was used. Later, as an improvement of the analysis, the Mooney three-parameter and Yeoh model were added.

\subsection{Theory}

The basis for any hyperelastic-material model is the strain energy density function W. In the general case of an anisotropic hyperelastic solid, the strain energy density function must be a symmetrical function of the stretch ratios $\lambda_{1}, \lambda_{2}$ and $\lambda_{3}$. Therefore, $W$ can be defined with three invariants $I_{1}, I_{2}, I_{3}$ given in next Equations (1-4):

$$
\begin{gathered}
I_{1}=\lambda_{1}^{2}+\lambda_{2}^{2}+\lambda_{3}^{2} \\
I_{2}=\lambda_{1}^{2} \lambda_{2}^{2}+\lambda_{2}^{2} \lambda_{3}^{2}+\lambda_{1}^{2} \lambda_{3}^{2} \\
I_{3}=\lambda_{1}^{2} \lambda_{2}^{2} \lambda_{3}^{2}
\end{gathered}
$$

Thus,

$$
W=f\left(\lambda_{1}, \lambda_{2}, \lambda_{3}\right)
$$

In a hyperelastic-material research, various models are used to define the strain energy function. The Mooney-Rivlin model is one of the frequently used models.

\subsection{Mooney-Rivlin model}

A suitable general form, a power series of the invariants $I_{1}, I_{2}$ considering the incompressibility of the material, is defined with Equation (5):

$W\left(I_{1}, I_{2}\right)=C_{10}\left(I_{1}-3\right)+C_{01}\left(I_{2}-3\right)$

In this equation, $C 10$ and $C 01$ are the material constants.

Further extension of the Mooney-Rivlin model, a three-parameter form, is defined as follows in Equation (6):

$W\left(I_{1}, I_{2}\right)=C_{10}\left(I_{1}-3\right)+C_{01}\left(I_{2}-3\right)+C_{11}\left(I_{1}-3\right)\left(I_{2}-3\right)(6)$

\subsection{Yeoh model}

In this model, the three-term function is considered and written as given in Equation (7):

$W\left(I_{1}\right)=C_{10}\left(I_{1}-3\right)+C_{20}\left(I_{1}-3\right)^{2}+C_{30}\left(I_{1}-3\right)^{3}$

\section{EXPERIMENTAL PART}

\subsection{Material}

Styrene-butadiene rubber (SBR), commonly used in the tyre-manufacturing industry, was used as the test material. For the experiments, all specimens were taken from the same rubber sheet prepared under uniform process conditions.

\subsection{Experimental tests}

In order to examine the mechanical behaviour of the above-mentioned elastomer material, three different deformation tests in the form of uniaxial, equibiaxial and pure shear were done. After obtaining the data for these tests separately, a regression analysis was done using the least square approach. Brief descriptions of the three tests are given below.

\subsection{Uniaxial-tension test}

This is a standard test. For this test, ISO 23529:2016 type-1 standard test pieces made of the martial mentioned above were used. Results were obtained at equal time durations and were recorded as engineering stress and engineering strain.

\section{Equibiaxial-tension test}

The use of an inflated rubber membrane for testing biaxial tension has a long history. It was first introduced by ${ }^{8}$. Since then, this method has been frequently used by scientists for testing rubber. ${ }^{9-11}$ As there is no standard method regarding the test, several variants of the bubble technique were used in different cases. However, the basic elements of the testing method in all the cases were the same. We adopted the method as described below.

A uniformly thin circular specimen shown in Figure 1, made of the test material, was held between two metal rings (jaws) of the apparatus. Then, pressurised air was introduced into the chamber where the top wall was the specimen back side. With the increasing pressure inside the chamber, the rubber membrane took the form of a dome or bubble. The pole of the bubble underwent equibiaxial tension and, therefore, a tiny area on the top of the bubble was used as the reference for the calculation of the strain. While pressure values were recorded at constant intervals, corresponding profile images of the inflated membrane were captured with a digital camera.

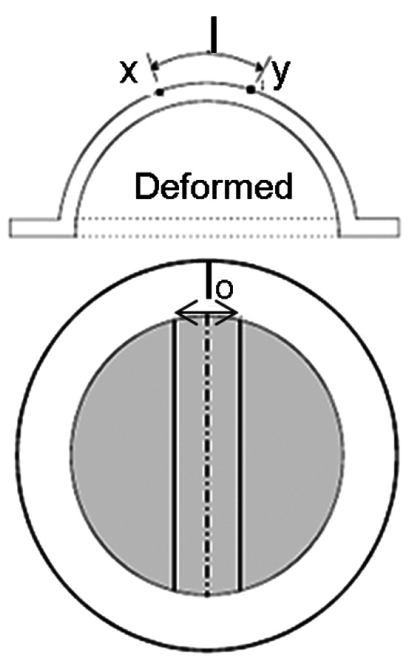

Rubber blank before

Figure 1: Equibiaxial specimen with related measurements

Materiali in tehnologije / Materials and technology 52 (2018) 1, 3-8 
The pressure inside the bubble was increased up to the bursting point of the bubble. A complete set of data was collected covering the full deformation of the specimen membrane.

The stretch ratio lambda $(\lambda)$ was calculated by comparing the length of the curvature between two marked positions (Figure 1) in each image and the undeformed specimen length $\left(l_{0}\right)$ corresponding to these points in Equation (8):

$$
\lambda=\frac{l}{l_{0}}
$$

By considering the material incompressibility, the hoop stress at the pole of the bubble $\left(\sigma_{\theta \theta}\right)$ can be expressed as follows in Equation (9):

$$
\sigma_{\theta \theta}=\frac{p \cdot r \cdot \lambda_{\theta \theta}^{2}}{2 t_{0}}
$$

In Equation (9), $p$ is the applied pressure, $t_{0}$ is the initial thickness of the specimen, $r$ is the radius of the curvature and $\lambda_{\theta \theta}$ is the stretch ratio at the pole.

\subsection{Pure-shear test}

The pure-shear test was done with a uniformly thin, rectangular $240 \mathrm{~mm} \times 24 \mathrm{~mm} \times 2 \mathrm{~mm}$ rubber sample. The centre line across the larger side was inked with two cross-hair marks (20 mm apart) for the reference purpose.

Planar-shear experiments are normally done with one dimension of the sample restricted with respect to deformation. ${ }^{12,13}$ Here, the specimen dimensions were selected in such a way that the deformation along one direction was very large compared to the deformation of the direction perpendicular to that. Thereby, the small deformation could be considered zero compared to the larger deformation. During the test, the specimen was

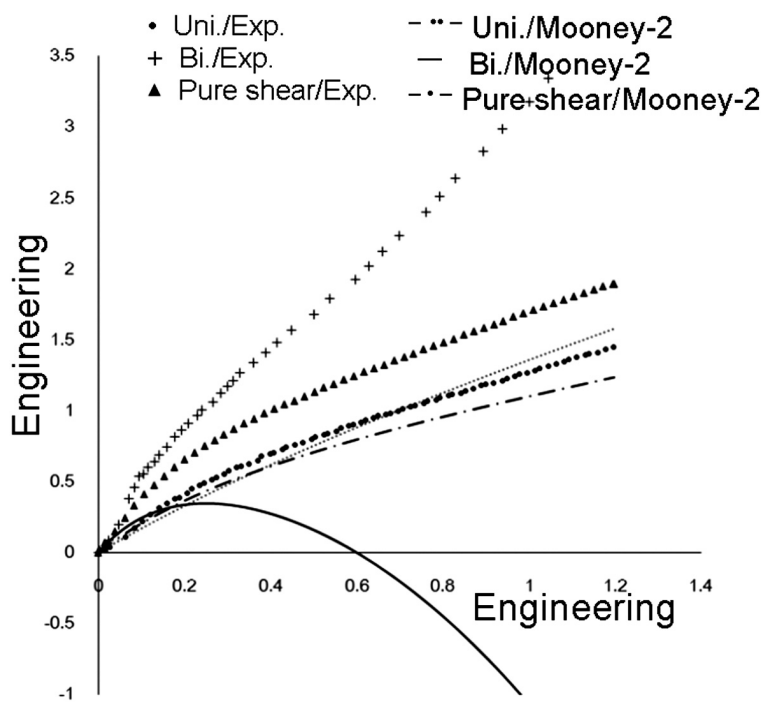

Figure 2: Uniaxial data fitting the Mooney two-parameter model graphs held between the jaws of the apparatus along the larger edge. The load and the elongation were recorded at several stages and the stress and the strain were calculated from the load and elongation data. Finally, the results were tabulated accordingly.

\section{RESULTS AND DISCUSSION}

The scientific work describes deformation curves obtained for three models through two different data-fitting methods. The uniaxial, equibiaxial and pure-shear curves provide for notable variations in these two separate instances and the following section describes the mentioned variations in detail. For the purpose of an easy identification, only uniaxial (OU) data fitting and combined, uniaxial and pure-shear (CUS) data fitting were used.

\subsection{Experimentally obtained data dispersion}

Regarding the dispersion of the three experimentaldata sets in the stress-strain domain, the following observations were noted. As evident from Figures 2 to 7, the biaxial-data set is located at a considerable distance from the other two data sets. The set of pure-shear data points is between the uniaxial- and biaxial-data sets, more inclined towards the uniaxial-data set. The uniaxial-data set is the closest to the strain axis.

Hence, at any given strain value, biaxial data shows the highest stress while uniaxial data shows the lowest stress. The pure-shear data for the same strain gives an intermediate value. This pattern can be observed in all the graphs.

\subsection{Mooney-Rivlin two-parameter model}

When referring to Figure 2, the first notable feature is a drastic deviation of the biaxial and pure-shear theoretical curves from the respective experimental-data

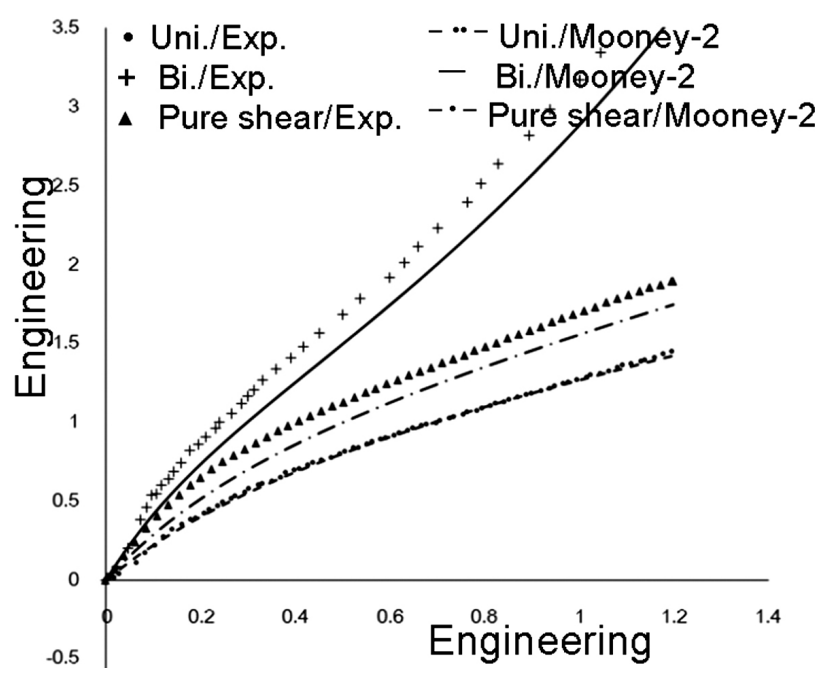

Figure 3: Combined data fitting the Mooney two-parameter model 


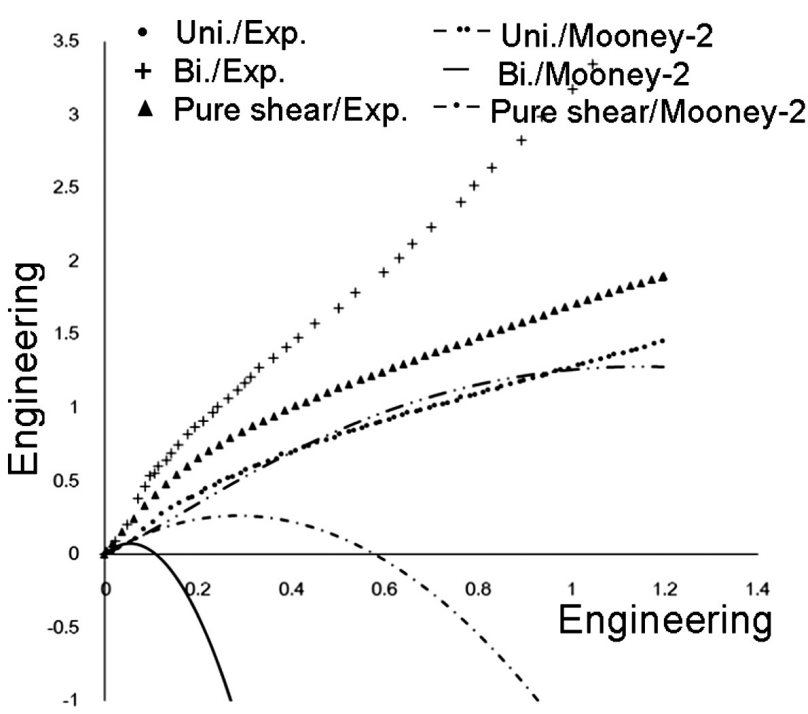

Figure 4: Uniaxial data fitting the Mooney three-parameter model graphs

sets. This discrepancy may have been caused because the data fitting was done with only one data set.

The second important feature is the near compatibility of the theoretical uniaxial curve with the data set. This is because the data fitting too was done with the uniaxial-data set. Furthermore, if we discuss the values of the residual sum of squares (RSS) given in Table 1, high values of the first two curves indicate the visible discrepancy mentioned above. However, the situation seems to be visibly improved with the combined data fitting (Figure 3). Comparatively low values obtained for RSS for both biaxial and pure-shear cases further establish the improvement with respect to the theoretical curves of the combined data fitting (Table 1). On the other hand, the theoretical uniaxial curve seems to be a bit degraded with the combined data fitting. A mode-

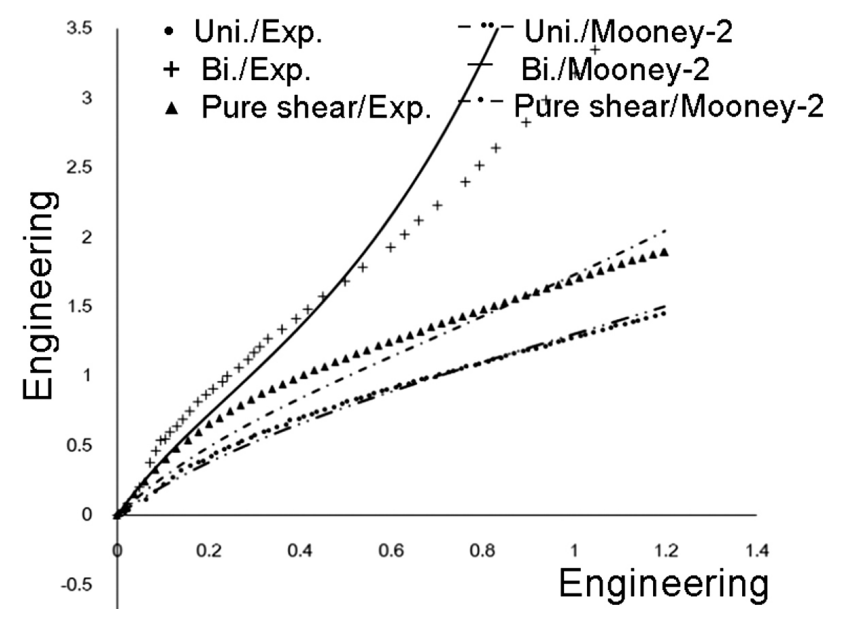

Figure 5: Combined uniaxial and pure-shear data fitting the Mooney three-parameter model graphs

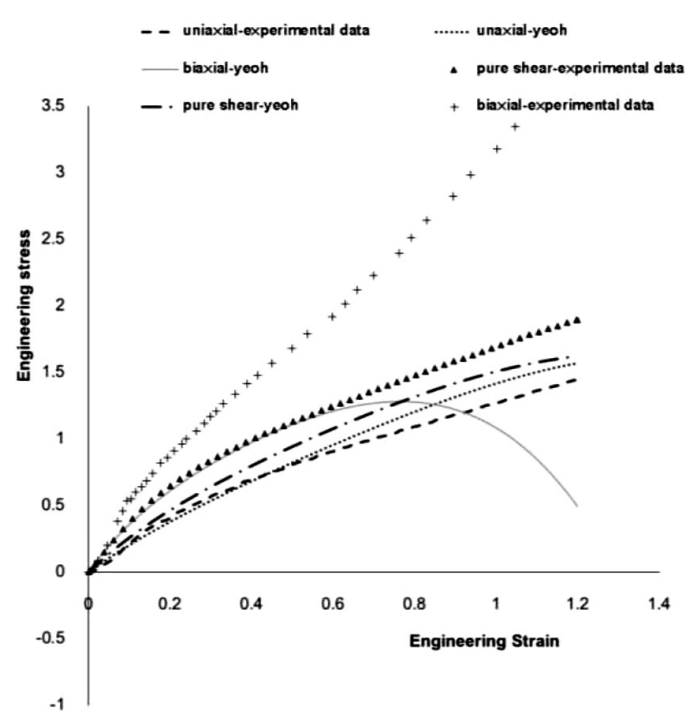

Figure 6: Uniaxial data fitting the Yeoh model graphs

rately higher value obtained for RSS in the case of the combined data fitting confirms this observation.

\subsection{Mooney-Rivlin three-parameter model}

Graphs in Figure 4 illustrate a relative dispersion of the theoretical curves against the experimental-data sets for the Mooney three-parameter model fitted only with the uniaxial data. Positions of the theoretical curves of the biaxial and pure shear seem to have further deteriorated as these two curves bend towards the negative stress region. However, the uniaxial curve does not appear to be affected by this.

At the same time, high values of RSS obtained for the initial two cases of the Mooney three-parameter model give further indication of the complete mismatch. The RSS value of the near unity achieved for the uniaxial curve means that the theoretical curve in this case nearly

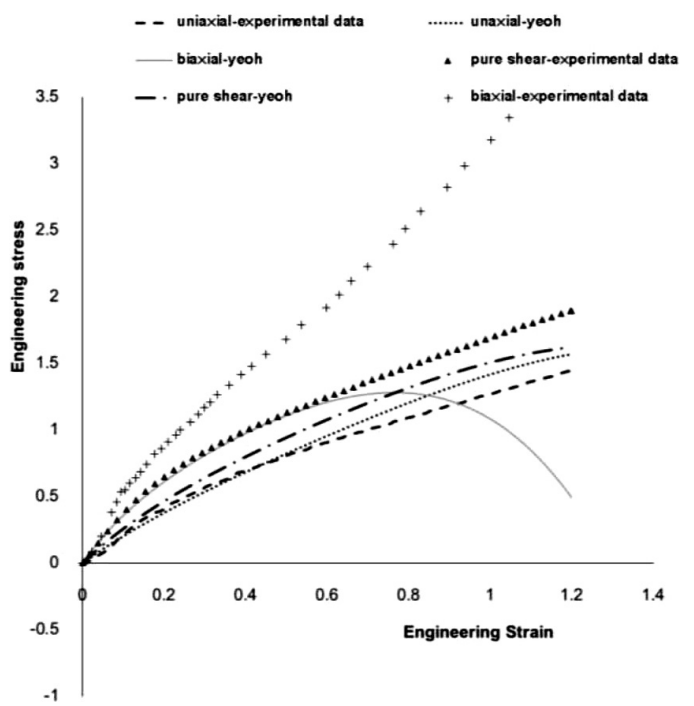

Figure 7: Combined uniaxial and pure-shear data fitting the Yeoh model graphs 
R. KEERTHIWANSA et al.: ELASTOMER TESTING: THE RISK OF USING ONLY UNIAXIAL DATA FOR FITTING ..

Table 1: Values of material parameters predicted using only uniaxial data and using combined data sets (both uniaxial and pure shear)

\begin{tabular}{|c|c|c|c|c|c|}
\hline \multirow{2}{*}{ Model } & \multirow{2}{*}{ Constant } & \multirow{2}{*}{ Value } & \multicolumn{3}{|c|}{ Residual sum of squares $(R S S)^{*}$} \\
\hline & & & Uniaxial & Biaxial & Pure shear \\
\hline \multirow{2}{*}{$\begin{array}{l}\text { Mooney two-parameter model } \\
\text { (Only uniaxial fitting) }\end{array}$} & $\mathrm{C} 10$ & 0.481348 & \multirow{2}{*}{1.7155} & \multirow{2}{*}{32.9896} & \multirow{2}{*}{7.99229} \\
\hline & $\mathrm{C} 01$ & -0.188224 & & & \\
\hline \multirow{2}{*}{$\begin{array}{l}\text { Mooney two-parameter model } \\
\text { (Combined uniaxial and pure-shear fitting) }\end{array}$} & $\mathrm{C} 10$ & 0.30894 & \multirow{2}{*}{3.419414} & \multirow{2}{*}{0.856019} & \multirow{2}{*}{1.026144} \\
\hline & $\mathrm{C} 01$ & 0.105854 & & & \\
\hline \multirow{3}{*}{$\begin{array}{l}\text { Mooney three-parameter model } \\
\text { (Only uniaxial fitting) }\end{array}$} & $\mathrm{C} 10$ & 1.06424 & \multirow{3}{*}{1.005845} & \multirow{3}{*}{967.2367} & \multirow{3}{*}{89.36178} \\
\hline & $\mathrm{C} 01$ & -0.838632 & & & \\
\hline & $\mathrm{C} 11$ & -0.127043 & & & \\
\hline \multirow{3}{*}{$\begin{array}{l}\text { Mooney three-parameter model } \\
\text { (Combined uniaxial and pure-shear fitting) }\end{array}$} & $\mathrm{C} 10$ & 0.28328 & \multirow{3}{*}{0.730736} & \multirow{3}{*}{82.77204} & \multirow{3}{*}{1.194405} \\
\hline & $\mathrm{C} 01$ & 0.107756 & & & \\
\hline & $\mathrm{C} 11$ & 0.0154692 & & & \\
\hline \multirow{3}{*}{$\begin{array}{l}\text { Yeoh } \\
\text { (Only uniaxial fitting) }\end{array}$} & $\mathrm{C} 10$ & 0.316354 & \multirow{3}{*}{1.910457} & \multirow{3}{*}{16.5195} & \multirow{3}{*}{3.979336} \\
\hline & $\mathrm{C} 20$ & 0.0491813 & & & \\
\hline & $\mathrm{C} 30$ & -0.0114659 & & & \\
\hline \multirow{3}{*}{$\begin{array}{l}\text { Yeoh } \\
\text { (Combined uniaxial and pure-shear fitting) }\end{array}$} & $\mathrm{C} 10$ & 0.368486 & \multirow{3}{*}{2.688881} & \multirow{3}{*}{7.415695} & \multirow{3}{*}{2.007579} \\
\hline & $\mathrm{C} 20$ & 0.0207127 & & & \\
\hline & $\mathrm{C} 30$ & -0.00394144 & & & \\
\hline
\end{tabular}

coincides with the actual data. When we talk about the combined fitting of this model, a certain improvement can be seen from all the results. However, the biaxial curve seems to deviate from the data values with the increased strain. A high RSS value visible in this particular situation might have been a result of this deviation.

\subsection{Yeoh model}

When we consider the Yeoh model, the curves fitted with a single data set, as given in Figure 6, provide results similar to those in the previous two cases. The only prominent feature here is a large deviation of the theoretical biaxial curve from the actual data. Even with the combined fitting effort, the theoretical biaxial curve does not seem to improve. Finally, the material constants and RSS values obtained as a result of the data-fitting efforts related to this work are presented below in Table $\mathbf{1}$.

With respect to Table 1, the residual sum of squares $(\mathrm{RSS})^{*}$ is defined as follows:

$$
R S S=\sum_{i=1}^{n}\left(\frac{\sigma_{m_{i}}-\sigma_{d_{i}}}{\sigma_{d_{i}}}\right)^{2}
$$

where $n$ is the number of data. Considering an arbitrary $i^{\text {th }}$ strain value, the theoretical stress value according to the model is given by $\sigma_{m}$ (a point on the curve) and the experimental stress data for the same strain is given by $\sigma_{d}$ (the actual data value).

\section{CONCLUSIONS}

In order to discuss the risk of using only uniaxial data for fitting hyperelastic-material models in general and the Mooney-Rivlin model in specific, an in-depth comparison was done. All three models show some improvement with combined-data fitting compared to only uniaxial-data fitting. Out of the three models, the
Mooney two-parameter model allows the best improvement. The Yeoh model seems to be the least responsive to the change of the data-fitting method. From the results of this work, it is evident that in order to obtain parameters for hyperelastic-material models through data fitting, the use of only one set of data, i.e., the uniaxial data is not sufficient.

\section{Acknowledgment}

This work and the project were realised with the financial support of an internal grant of the TBU in Zlin, No. IGA/FT/2017/002, funded from the resources for the specific university research.

\section{REFERENCES}

${ }^{1}$ E. I. Arruda, M. C. Boyce, A three-dimensional constitutive model for the large strength behaviour of rubber elastic materials, J. Mech. Phys. Solids, 41 (1993) 2, 389-412, doi:10.1016/0022-5096(93) 90013-6

${ }^{2}$ L. Hoss, R. J. Marczak, A new constitutive model for rubber-like materials, Mecánica Computacional, XXIX (2010), 2759-2773

${ }^{3}$ G. L. Bradley, P. C. Chang, G. B. Mckenna, Rubber Modeling Using Uniaxial Test Data, J. Applied Polymer Science, 81 (2001), 837-848

${ }^{4}$ G. Marckmann, E. Verron, P.-E. Austreii, L. Kari, Efficiency of hyperelastic models for rubber-like materials, Rubber Chemistry and Technology, American Chemical Society, 79 (2005) 5, 835-858

${ }^{5}$ C. Vlad, G. Prisacaru, D. Olaru, FEM Simulation on Uniaxial Tension of Hyperelastic Elastomers, Applied Mechanics and Materials, 659 (2014), 57-62, doi:10.4028/www.scientific.net/AMM.659.57

${ }^{6}$ R. Kottner, J. Kocáb, J. Heczko, J. Krystek, Investigation of the mechanical properties of a cork rubber composite, Materials and Technology, 50 (2016) 4, 579-583, doi:10.17222/mit.2015.172

${ }^{7}$ M. Sasso, G. Palmieri, G. Chiappini, D. Amodio, Characterization of hyperelastic rubber-like materials by biaxial and uniaxial stretching tests based on optical methods, Polymer Testing, 27 (2008) 8, 995-1004, doi:10.1016/j.polymertesting.2008.09.001

${ }^{8}$ L. R. G. Treloar, Stress-strain data for vulcanised rubber under various types of deformation, Trans. Faraday Soc., 40 (1944), 59-70, doi:10.1039/TF9444000059 


\section{R. KEERTHIWANSA et al.: ELASTOMER TESTING: THE RISK OF USING ONLY UNIAXIAL DATA FOR FITTING ...}

${ }^{9}$ J. Javorik, D. Manas, The specimen optimisation for the equibiaxial test of elastomers, https://www.researchgate.net/publication/ 261844574, 2016

${ }^{10}$ M. Rachik, F. Schmidt, N. Reuge, Y. Le Maoult, F. Abbe, Elastomer biaxial characterization using bubble inflation technique, Numerical investigation of some constitutive models, J. Polymer Engineering and Science, 41 (2001) 3, 532-541, doi:10.1002/pen.10750

${ }^{11}$ A. Bojtos, G. Abraham, Optical measuring system for equibiaxial test of hyperelastic rubber-like materials, Youth symposium on experimental solid mechanics, (2010), 170-173
${ }^{12}$ M. Shahzad, A. Kamran, M. Z. Siddiqui, M. Farhan, Mechanical characterization and FE modelling of a hyperelastic material, Materials Research, 18 (2015) 5, 918-924, doi:10.1590/1516-1439. 320414

${ }^{13}$ J. Gough, A. H. Muhr, A. G. Thomas, Material characterisation for finite element analysis of rubber components, J. Rubb. Res., 1 (1998) 4, 222-239

${ }^{14}$ A. F. Bower, Applied Mechanics of Solids, CRC Press, 2009

${ }^{15}$ S. C. Chapra, Applied Numerical Methods with MATLAB for engineers and scientists, McGraw-Hill Publishers, 2012 